\title{
GAYA KEPEMIMPINAN DALAM PENGAMBILAN KEPUTUSAN TERHADAP SEBUAH ORGANISASI
}

Oleh :

\section{NOVITA ALFIAN \\ VEBRI ARIA R.}

\begin{abstract}
Abstrak
Peran kepemimpinan adalah seperangkat perilaku yang diharapkan, dilakukan oleh orang-orang sesuai dengan posisinya sebagai pemimpin. Peran pemimpin sangat besar dalam mengambil keputusan dan mengambil tanggung jawab atas hasilnya. Keputusan tersebut mencerminkan karakter seorang pemimpin. Pengambilan keputusan sangat penting bagi aktivitas organisasi juga merupakan kepemimpinan kunci atau inti kepemimpinan.

Pemimpin harus dapat mengambil keputusan dalam berbagai situasi, dengan memilih yang terbaik di antara sejumlah keputusan alternatif alternatif yang dihadapinya. Alternatidf harus dipilih yang memiliki risiko negatif terkecil sehingga tidak membahayakan organisasi. Pemimpin harus bisa menjelaskan alasannya - alasan memilih satu keputusan alternatif dengan cara yang paling mudah dipahami agar mendapat dukungan dalam pelaksanaannya.
\end{abstract}




\section{Pendahuluan}

Dalam organisasi pemerintah maupun organisasi swasta, Pemimpin adalah merupakan orang yang memegang komando, sehingga karena organisasi itu akan melangkah tergantung pada pemimpin itu,, Namum demikian seorang pemimpin tidak akan mampu melaksanakan tugasnya hanya seorang diri saja, oleh karena itu harus bekerja sama dengan orang lain. Hal ini seperti pendapat Ralp Shurier Davis, bahwa

“ organisasi adalah suatu kelompok orang - orang yang sedang bekerja kearah tujuan bersama dibawah kepemimpinan “. Demikian juga dalam usaha menumbuhkan partisipasi dalam proses pengambilan keputusan seperti yang disampaikan Prof. Dr. Sondang. P. Siagian:

"Seseorang pemimpin yang baik adalah orang yang tidak melaksanakan sendiri tindakan tindakan yang bersifat operasional, tetapi mengambil keputusan, menentukan kebijaksanaan dengan menggunakan orang lain untuk melaksanakan keputusan yang telah diambil sesuai dengan kebijaksanaan yang telah digariskan"

Salah satu tugas penting seorang pemimpin adalah untuk menentukan yang terbaik bagi organisasi dan para anggotanya. Namun dalam mengambil keputusan terkadang pemimpin menghadapi dilemma . adakalanya pemimpin ternyata mengambil keputusan yang salah dan merugikan organisasi. Kecepatan dan ketepatan seorang pemimpin dalam mengambil keputusan lazimnya menjadi tolok ukur kopetensi dan kredibilitas yang dimilikinya.

Pengambilan keputusan merupakan suatu hal yang sangat penting bagi individu maupun organisasi. Mengambil keputusan kadang-kadang mudah tetapi lebih sering sulit sekali. Kemudahan atau kesulitan mengambil keputusan tergantung pada banyaknya alternatif yang tersedia. Semakin banyak alternatif yang tersedia, kita akan semakin sulit dalam mengambil keputusan. Keputusan yang diambil memiliki tingkat yang berbeda-beda. Ada keputusan yang tidak terlalu berpengaruh terhadap organisasi, tetapi ada keputusan yang dapat menentukan kelangsungan hidup organisasi. Oleh karena itu, hendaknya mengambil keputusan dengan hatihati dan bijaksana. Artikel ini mengangkat permasalahan: "bagaimana peran kepemimpinan dalam pengambilan keputusan suatu organisasi? 


\section{Kepemimpinan}

Kepemimpinan dalam pengertian umum adalah menunjukkan proses kegiatan seseorang dalam pemimpin, membina,membimbing, mempengaruhi dan mengontrol pikiran, perasaan atau tingkah laku orang lain. Menurut Miftah Thoha, Kepemimpinan adalah : kegiatan untuk mempengaruhi perilaku orang lain atau seni mempengaruhi perilaku manusia, baik secara perorangan atau kelompok. Sedangkan menurut, Soerjono Soekamto, Kepemim-pinan adalah:

"Kemampuan dari seseorang pemimpin atau leader untuk mempengaruhi orang lain (orang yang dipimpin atau pengikutya) sehingga orang lain tersebut bertingkah laku sebagaimana yang dikehandaki oleh pemimpi"

Kepemimpinan dalam kaitannya dengan tipe - tipe pemimpin menurut Prof. Dr. Sondang P. Siagian menggolangkan dalam 5 tipe pemimpin yaitu: (1) tipe pemimpin yang otokratis; (2) tipe pemimpin yang militeristis; (3) tipe pemimpin yang paternalis; (4) tipe pemimpin yang kharismatis; (5) tipe pemimpin yang demikratis.

G.R. Terry menyatakan bahwa syarat - syarat kepemimpinan berkaitan dengan pengambilan keputusan adalah sebagai berikut: (1) 1. realistis; (3) banyak akal; (3) dapat mengambil inisiatif; (4) emosional stabil; (5) merupak seorang komunikator yang stabil; (6) partisipatif dalam bidang social.

\section{Gaya Kepemimpinan}

\section{Kepemimpinan Otokratis}

Pemimpin sangat dominan dalam setiap pengambilan keputusan dan setiap kebijakan, peraturan, prosedur diambil dari idenya sendiri. Kepemimpinan jenis ini memusatkan kekuasaan pada dirinya sendiri. Ia membatasi inisiatif dan daya pikir dari para anggotanya. Pemimpin yang otoriter tidak akan memperhatikan kebutuhan dari bawahannya dan cenderung berkomunikasi satu arah yaitu dari atas (pemimpin) ke bawah (anggota). Jenis kepemimpinan ini biasanya dapat kita temukan di akademi kemiliteran dan kepolisian.

\section{Kepemimpinan Birokrasi}

Gaya kepemimpinan ini biasa diterapkan dalam sebuah perusahaan dan akan efektif apabila setiap karyawan mengikuti setiap alur prosedur dan melakukan tanggung jawab rutin setiap hari. Tetap saja dalam gaya kepemimpinan ini tidak ada ruang bagi para anggota untuk melakukan inovasi karena semuanya sudah diatur dalam sebuah tatanan prosedur yang harus dipatuhi oleh setiap lapisan.

\section{Kepemimpinan Partisipatif}

Dalam gaya kepemimpinan partisipatif, ide dapat mengalir dari bawah (anggota) karena posisi kontrol atas pemecahan suatu masalah dan pembuatan keputusan dipegang secara bergantian. Pemimpin memberikan ruang gerak bagi para bawahan untuk dapat berpartisipasi dalam pembuatan suatu keputusan serta adanya suasana persahabatan dan hubungan saling percaya antar pimpinan dan anggota. 


\section{Kepemimpinan Delegatif}

Gaya kepemimpinan ini biasa disebut Laissez-faire dimana pemimpin memberikan kebebasan secara mutlak kepada para anggota untuk melakukan tujuan dan cara mereka masingmasing. Pemimpin cenderung membiarkan keputusan dibuat oleh siapa saja dalam kelompok sehingga terkadang membuat semangat kerja tim pada umumnya menjadi rendah. Jenis kepemimpinan ini akan sangat merugikan apabila para anggota belum cukup matang dalam melaksanakan tanggung jawabnya dan memiliki motivasi tinggi terhadap pekerjaan. Namun sebaliknya dapat menjadi boomerang bagi perusahaan bila memiliki karyawan yang bertolak belakang dari pernyataan sebelumnya.

\section{Kepemimpinan Transaksional}

Kepemimpinan jenis ini cenderung terdapat aksi transaksi antara pemimpin dan bawahan dimana pemimpin akan memberikan reward ketika bawahan berhasil melaksanakan tugas yang telah diselesaikan sesuai kesepakatan. Pemimpin dan bawahan memiliki tujuan, kebutuhan dan kepentingan masing-masing.

\section{Kepemimpinan Transformasional}

Gaya kepemimpinan transformasional dapat menginspirasi perubahan positif pada mereka (anggota) yang mengikuti. Para pemimpin jenis ini memperhatikan dan terlibat langsung dalam proses termasuk dalam hal membantu para anggota kelompok untuk berhasil menyelesaikan tugas mereka. Pemimpin cenderung memiliki semangat yang positif untuk para bawahannya sehingga semangatnya tersebut dapat berpengaruh pada para anggotanya untuk lebih energik. Pemimpin akan sangat mempedulikan kesejahteraan dan kemajuan setiap anak buahnya.

\section{Kepemimpinan Melayani (Servant)}

Hubungan yang terjalin antara pemimpin yang melayani dengan para anggota berorientasi pada sifat melayani dengan standar moral spiritual. Pemimpin yang melayani lebih mengutamakan kebutuhan, kepentingan dan aspirasi dari para anggota daripada kepentingan pribadinya.

\section{Kepemimpinan Karismatik}

Pemimpin yang karismatik memiliki pengaruh yang kuat atas para pengikut oleh karena karisma dan kepercayaan diri yang ditampilkan. Para pengikut cenderung mengikuti pemimpin karismatik karena kagum dan secara emosional percaya dan ingin berkontribusi bersama dengan pemimpin karismatik. Karisma tersebut timbul dari setiap kemampuan yang mempesona yang ia miliki terutama dalam meyakinkan setiap anggotanya untuk mengikuti setiap arahan yang ia inginkan.

\section{Kepemimpinan Situasional}

Pemimpin yang menerapkan jenis kepemimpinan situasional lebih sering menyesuaikan setiap gaya kepemimpinan yang ada dengan tahap perkembangan para anggota yakni sejauh 
mana kesiapan dari para anggota melaksanakan setiap tugas. Gaya kepemimpinan situasional mencoba mengkombinasikan proses kepemimpinan dengan situasi dan kondisi yang ada.

Setidaknya ada 4 gaya yang diterapkan oleh pemimpin jenis ini, diantaranya:

a. Telling-Directing (memberitahu, menunjukkan, memimpin, menetapkan),

b. Selling-Coaching (menjual, menjelaskan, memperjelas, membujuk),

c. Participating-Supporting (mengikutsertakan, memberi semangat, kerja sama),

d. Delegating (mendelegasi, pengamatan, mengawasi, penyelesaian).

\section{Pengambilan Keputusan}

Pengambilan keputusan merupakan proses pembuatan pilihan dari sejumlah alternative. Menurut G.R. Terry . Pengambilan Keputusan adalah pemilihan alternative perilaku tertentu atau dari dua atau lebih alternative yang ada. Sedangkan menurut Prof.Dr.Sondang. P. Siagian , Pengambilan keputusan adalah suatu pendekatan yang sistematis terhadap hakekat alternative yang dihadapi dan mengambil tindakan yang menurut perhitungan merupakan tindakan yang paling cepat. Keputusan lahir dari suatu proses, dimana didalammnya terjadi diskusi yang intensif, saling tukar pikiran dan brainstorming yang mendalam dengan analisis yang tajam. Oleh sebab itu pengambilan keputusan sangat penting dalm pengelolaan dan merupan tugas utama dari seorang pemimpin. Adapun hasil dari pengambilan keputusan adalah aturan - aturan yang akan dijadikan pegangan untuk mengarahkan tingkah laku selanjutnya. Fokus pengambilan keputusan adalah pada kemampuan untuk menganalisis situasi dengan memperoleh informasi seakurat mungkin sehingga permasalahan dapat dituntaskan. Jenis Keputusan dalam sebuah organisasi dapat digolongkan berdasarkan banyaknya waktu yang diperlukan untuk mengambil keputusan tersebut. Bagian mana organisasi harus dilibatkan dalam mengambil keputusan, dan pada bagian organisasi mana keputusan tersebut difokuskan.

Secara garis besar keputusan digolongkan ke dalam keputusan rutin dan keputusan yang tidak rutin. Keputusan rutin adalah keputusan yang sifatnya rutin dan berulang-ulang, dan biasanya telah dikembangkan cara tertentu untuk mengendalikannya. Keputusan tidak rutin adalah keputusan yang diambil pada saat-saat khusus dan tidak bersifat rutin.

Pengambil keputusan, baik yang bersifat rutin maupun tidak, ada dua metode yang digunakan. Metode pertama adalah metode tradisional, dimana pengambilan keputusan lebih berdasarkan pada intuisi dan kebiasaan. Metode yang kedua adalah metode modern, dimana pengambilan keputusan didasarkan pada perhitungan matematis dan penggunaan instrumen yang bersifat modern, seperti komputer dan perhitungan statistik.

Dasar pengambilan keputusan menurut G.R. Terry adalah sebagai berikut: pertama Intuisi. Suatu proses bawah sadar / tidak sadar yang timbul atau tercipta akibat pengalaman terseleksi. Pengambilan Keputusan yang berdasarkan atas intuisi atau perasaan memiliki sifat subyektif, sehingga mudah terkena pengaruh.

Kedua pengalaman. Pengambilan keputusan berdasarkan pengalaman memiliki manfaat bagi pengetahuan praktis, karena pengalaman seseorang dapat memperkirakan keadaan sesuatu, 
dapat memperhitungkan untung ruginya, baik buruknya keputusan yang akan dihasulkan, karena pengalaman seseorang yang menduga - duga masalhnya walaupun hanya dengan melihat sepintas saja mungkin sudah dapat menyelesaikannya.

Ketiga fakta. Pengambilan keputusan berdasarkan fakta dapat memberikan keputusan yang sehat, solid dan baik. Dengan fakta maka tingkat kepercayaan terhadap pengambilan keputusan dapat lebih tinggi, sehingga orang dapat menerima keputusan - keputusan yang dapat dengan rela dan lapang dada.

Keempat wewenang.Pengambilan Keputusan berdasarkan wewenang biasanya dilakukan oleh pimpinan terhadap bawahannya atau orang lain yang lebih tinggi kedudukannya kepada yang lebih rendah kedudukannya.

Kelima rasional. Pengambilan Keputusan berdasarkan Rasional, keputusan yang dihasilkan bersifat obyektif, lebih transparan,konsisten, untuk memaksimalkan hasil atau nilai dalam batas kendala tertentu, sehingga dapat dikatakan mendekati kebenaran atau sesuai dengan apa yang diinginkan. Ada beberapa hal yang harus diperhatikan : kejelasan masalah, Orientasi tujuan, Pengetahuan alternative,Preferensi yang jelas, Hasil maksimal.

Proses pengambilan keputusan harus melalui tahapan - tahapan tertentu dengan tertip. Seperti yang dikemukankan oleh Charles Hoffer, yaitu: Distinguished the phases initition and legitimation ( artinya bahwa untuk mengenali tahapan - tahapan dalam membuat suatu keputusan yaitu tahan Permulaan ( initition ) dan tahap pengesahan (legitimation). Setelah mengetahui tahap - tahap pengambilan keputusan, kemudian untuk mendapatkan keputusan pasti melalui beberapa proses, Menurut Herbert A. Simon mengemukakan tiga proses dalam pengambilan keputusan yaitu: (1) Inteligence Activity, yaitu : proses pemilihan situasi dan kondisi dengan wawasan yang inteligen; (2) Design Activity, aitu proses menemukan masalah, mengembangkan pemahaman dan menganalisis kemungkinan pemecahan masalah serta tindakan lebih lanjut, ada perencanaan pola kegiatan; (3) Choise Activity, yaitu memilih salah satu tindakan dari sekian banyak alternative atau kemungkinan pemecahan, dan diambil keputusan.

Ada tujuh kriteria yang dapat digunakan apakah prosedur pengambilan keputusan memiliki mutu yang tinggi, yaitu:

1. Secara menyeluruh mengumpulkan berbagai macam cakupan yang luas dari suatu tindakan alternative,

2. Mensurvei semua cakupan tentang hasil dari sasaran yang harus dipenuhi dan nilai nilai yang mencakup sebuah pilihan,

3. Secara hati - hati menimbang apa pun konsekuensi yang negative,

4. Secara intensif mencari informasi baru yang relevan untuk dievaluasi dari alternative,

5. Dengan tepat berasimilasi dan memperhatikan penilaian yang diberikan oleh para ahli dan informassi yang baru,

6. Memeriksa kembali konsekuensi yang negative dan posistif dari semua alternative,

7. Ketentuan yang terperinci untuk menerapkan tinakan yang terpilih.

Beberapa metode Pengambilan Keputusan yang dapat digunakan dalam organisasi antara lain: (1) Kewenangan tanpa diskusi, metode ini sering digunakan kalangan militer dan cepat 
dalam memutuskan dan cocok kalu pengambilan keputusan yang dilaksanakan berkaitan dengan persoalan rutin yang tidak perlu didiskusikan; (2) Pendapat ahli, metode ini akan bekerja dengan baik, apabila seseorang anggota kelompok yang dianggap ahli tidak diragukan kemampuannya dalam hal tertentu oleh anggotanya; (3) Kesepakatan, metode ini melibatkan berbagai unsure dalam mengambil sebauah keputusan, seluruh anggota berpartisipasi penuh. Metode ini sangat penting khusus yang berhubungan dengan persoalan yang kritis dan komplek.

Ketepatan penggunaan dari ketiga metode tersebut harus disesuaikan dengan: (1) Jumlah waktu yang ada dan dapat dimanfaatkan; (2) Kemampuan - kemampuan yang dimiliki oleh pemimpin kelompok dalam mengelola kegiatan pengambilan keputusan; dan (3) Tingkat pentingnya keputusan yang akan diambil oleh kelompok.

Ada beberapa hal proses pengambilan keputusan sebagai berikut: (1) Persepsi sesorang tentang situasi lingkungan sangat penting dan peka terhadap situasi yang mungkin menjadi penyebab timbulnya masalah; (2) Berusaha memahami sesungguhnya yang sedang terjadi dalam situasi masalah tertentu; (3) Mendefinisikan masalah yang dihadapi untuk dipecahkan;

(4) Menenntukan alternative dari pada metode dan cara pemecahan; (5) Pelaksanaan alternative terpilih berdasarkan analisis yang mendalam yang pada gilirannya berubah wujud menjadi keyakinan, ketepatan pilihan dan efektif.

Berikut ini merupakan penjabaran proses pengambilan keputusan:

\section{Pengambilan keputusan}

Pengambilan keputusan pada dasarnya adalah proses pemecahan masalah yang menghalangi atau menghambat tercapainya tujuan. Agar masalah dapat dipecahkan, terlebih dahulu harus dikenali apa masalahnya.

\section{Mencari alternatif pemecahan}

Setelah masalh dikenali maka dapat dilakukan pencarian terhadap alternatif-alrternatif yang mungkin dapat memecahkan masalah yang dihadapi. Dalam mencari alternatif hendaknya tidak mamikirkan masalah efisiensi dan efektifitas.Yang terpenting adalah mengumpulkan sebanyakbanyaknya alternatif. Setelah alternatif terkumpul, barulah disusun berurutan dari yang paling diinginkan sampai yang tidak diinginkan.

\section{Memilih alternatif}

Setelah alternatif tersusun, barulah dapat dilakukan pilihan alternatif yang dapat memberikan manfaat, dalam arti dapat memecahkan masalah dengan cara yang paling efektif dan efisien. Sebelum menjatuhkan pilihan pada sebuah alternatif, ajukan pertanyaan untuk tiap-tiap alternatif.

\section{Pelaksanaan alternatif}

Setelah alternatif dipilih, tibalah saatnya melaksanakannya ke dalam bentuk tindakan. pelaksanaan harus sesuai denga rencana, agar tujuan memecahkan masalh dapat tercapai.

\section{Evaluasi}

Setelah alternatif dilaksanakan, bukan berarti proses pengambilan keputusan telah selesai. Pelaksanaan alternatif harus terus diamati, apakah berjalan sesuai dengan yang diharapkan. Bila langkah-langkah pelaksanaan telah dilakukan dengan benar tetapi hasil yang dicapai tidak maksimal, sudah waktunya untuk mempertimbangkan kembali pemilihan alternatif lainnya. 
Tidak maksimalnya hasil yang dicapai mungkin terjadi karena pengaruh negatif potensial benarbenar terjadi, atau mungkin pengaruh negatif yang tadinya tidak diperkirakan.

Pengambilan keputusan memerlukan keberanian, karena setiap keputusan pasti memiliki resiko, Fungsi pengambilan keputusan sebagai strategi kepemimpinan sangat penting perannya. Keberanian pengambikan keputusan bagi organisasi berarti pemimpinnya mengetahui cara mencapai tujuan organisasi yang akan memberikan manfaat pada semua anggota organisasi. Seorang pemimpin harus mampu mengkomunikasikan keputusan yang telah ditetapkan pada anggota organisasi untuk dilaksanakan.

Kekuasaan yang lebih besar yang dimiliki oleh pemimpin dalam pengambilan keputusan perlu dilaksanakan dengan demokratis antara lain dengan : melibatkan semua pihak, membentuk tim - tim khusus yang diberi wewenang mengambil keputusan yang relevan dan menjalin kerjasama dengan lembaga - lembaga lain.

\section{Peran Kepemimpinan}

Peran Kepemimpinan diartikan sebagai seperangkat perilaku yang diharapkan dilakukan oleh seseorang sesuai dengan kedudukannya sebagai pemimpin. Peran pemimpin sangat besar dalam pengambilan keputusan dan mengambil tanggung jawab terhadap hasilnya. Seseorang pemimpin dituntut untuk memiliki ketrampilan yaitu, ketrampilan teknis meliputi ketrampilan dalam menerapkan pengetahuan dan keahlian yang dimiliki, ketrampilan manusiawi meliputi kemampuan kerjasama, memahami dan memotivasi orang lain dan ketrampilan konseptual barkaitan dengan kemampuan pengambilan keputusan. Pengambilan keputusan terjadi sebagai reaksi terhadap masalah yang terjadi dalam organisasi. Keputusan harus dibuat oleh pemimpin agar anggota dapat melaksanakan berbagai kegiatan dalam rangka mewujudkan dan mengembalikan eksistensi organisasi.

Ada tiga peran utama seorang pemimpin yaitu: (1) Peran yang bersifat interpersonal. Artinya seorang pemimpin harus tampi, dalam berbagai upacara remi, harus mampu member bimbingan dan harus mempertimbangkan hubungan kerjasama dengan bawahan; (2) Peran yang bersifat informasional, informasi kepada bawahan dan menjadi juru bicara organisasi. Artinya seorang pemimpin harus mengikuti dan memperoleh informasi seluruh kegiatan, harus memberi; (3) Peran yang bersifat Pengambilan keputusan. Artinya seorang pemimpin harus berusaha memperbaiki dan mengembangkan satuan kerja yang dipimpinnya, harus mampu mengatassi segala hambatan yang dihadapi, mengatur segala sumber daya (manusia, biaya dan lain - lain ) dan berperan mewakili setiap hubungan kerja dengan satuan kerja lainnya . Peran pemimpin dalam pengambilan keputusan biasanya bersama - sama dengan bawahan melakukan pemilihan beberapa alternative yang ada untuk menentukan tujuan yang ingin dicapai.Proses Pengambilan keputusan harus mempertimbangkan segala aspek dan sesuai kebutuhan. Informasi yang cukup baik, maka keputusan yang dibuat terjamin tingkat keakuratannya. 
Perilaku kepemimpinan merupakan aktivitas yang selalu berorientasi tujuan mencakup aktivitas mengambil keputusan menyusun sasaran, komunikasi interpersonal, perilaku keteladanan, memberi imbalan dan hukuman yang ditampilkan pemimpin untuk mempengaruhi anggota melakukan pekerjaan untuk mencapai tujuan. Pengambilan keputusan adalah bahagian aktivitas penting dalam proses kepernimpinan dalam organisasi. Proses pengambilan keputusan mencakup, mengenali masalah, menganilisis masalah, mengembangkan alternatif, memutuskan solusi terbaik dan melaksanakan keputusan kedalam tindakan efektif' . Proses kepemimpinan di dalamnya melekat wewenang dan tanggung jawab menyusun program kerja, melaksanakan dan mengevaluasi dengan mengarahkan bawahannya dalam melakukan program kerja. Pimpinan setiap organisasi harus mempermudah proses pengambilan keputusan dan komunikasi keputusan terhadap semua anggota organisasi untuk mendapat dukungan pelaksanaan keputusan.

Pemimpin diasosiasikan dengan pengembangan dan pengkomunikasian sebuah visi . Mengkomunikasikan sesuatu yang ada dalam visi menyiratkan tentang sifat kepemimpinan. Karena itu pemimpin diharapkan dapat mendorong dan meningkatkan keterlibatan dan pemahaman staf. Keputusan efektif tercapai jika sepenuhnya keputusan itu dapat dilaksanakan. Perhatian orang akan sepenuh hati ke dalam suatu keputusan jika mereka terlibat secara langsung atau tidak langsung dalam membuat keputusan. Suatu cara yang efektif untuk mencapai dukungan dan komitmen dengan mengajak staf atau anggota organisasi dalam pemecahan masalah-pada tahap penyusunan sasaran. Strategi kolaboratif pengambilan keputusan mengilhami para staf atau dengan rasa pemberdayaan dan perasaan penting yang memuaskan dorongan kebutuhan mereka. Dengan demikian pimpinan perlu melibatkan semua staf atau anggota organisasi dalam mengambil keputusan agar muncul rasa memiliki dan tanggung jawab dalam melaksanakan keputusan. Pembuatan keputusan partisipatori akan dapat diharapkan menghasilkan lebih baik keputusan, sebab sejumlah pemikiran orang dimanfaatkan untuk memecahkan masalah. Bahkan bila orang dilibatkan dalam membuat keputusan, mereka lebih suka uniuk melaksanakan keputusan secara efektif dan peningkatan pengertian karena keterlibatan langsung serta membantu kesatuan kelompok dalam organisasi.

Efektivitas keputusan bergantung kepada kualitas keputusan dan komitmen keputusan. Kualitas keputusan mengacu kepada aspek teknis dalam keputusan. Keputusan berkenaan dengan kualitas tinggi untuk pengembangan yang dalam hal ini keputusan bersifat konsisten dengan tujuan organisasi yang dicapai dan dengan informasi yang secara potensial dapat diperoleh. Sedangkan komitmen keputusan mengacu kepada penerimaan keputusan oleh sataf atau anggota organisasi. Partisipasi dalam keputusan oleh staf atau anggota organisasi cenderung menghasilkan perasaan komitmen dan rasa memiliki bersama. Partisipasi dalam keputusan dapat membangun tim kerja, kekuatan komitmen terhadap sasaran organisasi, dan kontribusi kepada pengembangan teknik partisipan dan keterampilan manajerial. Perilaku pemimpin memiliki pengaruh atas kinerja dan kepuasan kerja anggota. Hal yang mendasar ditekankan bahwa kinerja dan kepuasan anggota adalah hasil dari ragam gaya kepemimpinan seorang pemimpin. Sikap positif orang terbangun terhadap objek yang merupakan alat dalam kepuasan kebutuhan. Hal ini 
menjadi alasan perluanya pengembangan hubungan pimpinan dengan bawahan. Ada hubungan timbal balik perilaku pimpinan dengan perilaku bawahan. Perilaku bawahan berpengaruh terhadap perilaku pimpinan dan perilaku pimpinan mempengaruhi perilaku bawahan.

Kepemimpinan seseorang dalam sebuah organisasi sangat besar perannya dalam setiap pengambilan keputusan, sehingga membuat dan mengambil tanggung jawab terhadap hasilnya adalah salah satu tugas pemimpin. Pengambilan Keputusan dalam tinjauan perilaku mencerminkan karakter bagi seorang pemimpin. Oleh karena itu baik tidaknya keputusan yang diambil bukan hanya dari konsekuensi yang diambilnya melainkan melalui berbagai pertimbangan dalam prosesnya.

\section{Penutup}

Pemimpin harus mampu mengambil keputusan dalam berbagai situasi, dengan memilih alternatis terbaik diantara sejumlah alternative keputusan yang dihadapinya. Alternatidf harus dipilih yang resiko negative nya paling kecil agar tidak merugikan organisasi. Pemimpin harus mampu menjelaskan alasan - alasan memilih salah satu alternative keputusan dengan cara yang paling mudah dipahami agar mendapat dukungan dalam pelaksanaannya. Pada dasarnya pengambilan keputusan adalah merupakan tahap - tahap yang harus digunakan untuk membuat keputusan. Pengambilan keputusan merupakan pusat dari kegiatan organisasi juga merupakan kunci kepemimpinan atau inti dari kepemimpinan. 


\section{Daftar Pustaka}

Kartini Kartono, 2000, Pemimpin dan Kepemimpinan, CV. Rajawali, Jakarta

Miftah Thoha, 2000 Kepemimpinan dalam Manajemen, CV. Rajawali, Jakarta

Sondang P. Siagian, 1987 Filsafat Administrasi, Gunung Agung, Jakarta

Timpe, A. Dale, 2002, Seri Manajemen

Sumber Daya Manusis : Kepemimpinan, PT. Gramedia, Jakarta

Dhino -ambargo, blogspot.com. Definisi dan Dasar Pengambilan Keputusan, 22 Mei 2013.

http://sellyinthewords.blogspot.com 